\section{Geophysical Theory}

Sir,--May I, while thanking Professor Runcorn for the greater part of his review of the new edition of The Earth (Nature, 227, 525; 1970), reply to his critical remarks concerning certain parts of it?

He refers to my "robust prejudxces" and states that I indulge in "selection (selective") quotation". I admit to a prejudice, namely that in an alleged explanation the conclusions should follow from the hypotheses, and that if the hypotheses lead to conclusions different from the facts theie is something wrong with them This prejudice is shared by most scientists

As for selection, I admit that I have not rodd every. thing published in support of continental drift I thunh that I have given reasons why the alleged explanation does not explain things that have happened and explains too many things that have not happened. On the other hand, I har $c$ not seen any work by a supporter of drift that even mentions that there are difficulties

From Runcorn's review it would be inferred that I have not treated imperfection of elasticity apait from fracture Following on the work described in the book (p. 331 et seq) Crampm and $\mathbf{I}^{12}$ have recently published further work, and the form that we find forbids convection and continental drift. It gives quantitative explanations of facts far beyond the original data. Most seismologists concerned with damping use a law that departs even more than ours from one type that permits convection

Since the final proofs were passed, there have been extensive and severe criticisms of continental drift from the geologieal point of view by Meyerhoft ${ }^{3}$ and Bisw as 4

\section{Yous faithfinlly,}

St John's College,

\section{Harold JeTFREYS}

Cambudge.

' Jeffreys, $H$ and ( sampun S Mon $\Lambda$ ot Roy Astron Soc, 147 290 (1970)

2 Jeffreys, $\mathrm{H}$, , I ature, $2251007(1970)$

${ }^{3}$ Meyerhoff, A A, J Geol, 78, 1 (1970).

- Biswas B, Rising Contrnents Deepening Oceanic Basins, and therr Changing Configuiation (B Bisw is Calcutta, 1970)

\section{Wayward Bacterium}

Srr,--Permit me to call to your attention evidence of a inisconception on the part of your writer responsible for the article "Lunar Bacteriology-Bacillus by Rocket" (Nature, 226, 1000, 1970). The question is asked, "But how did the bacterium escape through the tight sterility net applied to all extraterrestrial space missions ""

Early in the decade of the 1960s there was concern for terrestrial contamination of the Moon; but as the matter was studied, it became apparent that, though terrestrial life might survive on the Moon, it could not multiply in that adverse cnvironment, and it could therefore be no threat to lunar life if it existed. Subsequently the only biological constraint on lunar missions has been the expressed opinion of the International Committec on Space Research (COSPAR) that careful sterilization is desirable for drills designed for deep lunar subsurface boring NASA has gone one step further, however, and on the basis of a recommendation by the Space Science Board of the National Academy of Sciences has kept its Junar landing hardwaic as biologically clean as was practi- cal. This action resulted in approximately $5 \times 10^{6}$ viable spores being aboard Surveyor 3 at the time of launch, as compared with $1 \times 10^{8}$ to $1 \times 10^{9}$ spores for a spaceciaft assembled without cleanliness controls.

In contrast is the constraint placed on planetary missions. COSPAR has recommended that lamching states assure that there shall be only one chance in one thousand of contaminating a planet deemed important for the investigation of extraterrestrial hife during the period of biological exploration NASA has closely adhered to this requixement by biasing the trajectory of non sterile flyby missions away from the planets sufficiently so that the probability of direct impact is very small and no cjecta can reach the atmosphere. When mission are launched to land capsules on Mars, those parts of the missions intended to land on the planet's surface will be stershzed to the extent that they will have a probabilutv of Jess than $1 \times 10^{-3}$ of contaminating the planet

The United States is very aware of and is actively engaged in meeting its responsibility to protect the planets from biological contamination carried on its spacecraft Its responsibilities with regard to the Moon have bren more than inet

\section{Yours fathfully}

LAWRLNCE B HWI

Planetary Qualantine Officer,

Bioscience Programs,

Office of Space Science and Applieations,

National Aeronauties and Space Admmintratıon

Washington D('20546.

\section{French Nuclear Tests}

Sir,--The welfare of South Parific communıtif is mereasingly at risk in the face of relentless testing of nuclear weapons in French Polynesid Public outcry in Europe prevented France from continuing her test progiarnme in Algeria. Howeres, the protesting rorees of small South Pacific governments have been ignored

We are faced with increasing evidence of the hazards of uncontrolled radiodetivity While the extrapolations of Sternglass ${ }^{1}$ may overstate the threat, we cannot be complacent. Similar, more moderate, warnıngs by Gofman and Tampln ${ }^{2}$ and others on the dangers of the infamous "permissible" level of radiation ar generally accepted in the seientific community.

While the lasting danger to the people of the South Pacific hes in a general atmospheric contamination which will be shared, to an extent, with the rest of the world, a more immediate throat exists from contammated fish Certain of the large migratory fish such as tuna might feed on smallor fish dependent on heavily cuntammated plankton drifting from the test area Such deadly migiatory fish could turn up in catches all over the Parific.

Coral reef organisms have a great capacity for conerntratung radionuclides Data of Odum and Odum ${ }^{3}$ show a thousand fold concentiation in coral Molluses also are notoriously efficiont concentrators of radionuclıdes and these organisms constitute a major pari of the diet of South Pacific Islanders

The French Defence Minıster, M Debré, while in Tahitı recently, had the audacity to say that atomic seisntists had "proved that the nuclear tests left no radioactive contamination in the area". Britush, Nrw Zealand and 